\title{
Students motivation for admission to study on the educational program "Physical Education and Recreation"
}

\author{
Akor Sitepu, Ardian Cahyadi, Herman Tarigan \\ Lampung University, Indonesia
}

DOI: https://doi.org/10.34142/HSR.2020.06.04.02

\begin{abstract}
How to Cite
Sitepu A, Cahyadi A, Tarigan H. Students motivation for admission to study on the educational program "Physical Education and Recreation". Health, Sport, Rehabilitation. 2020;6(4):18-26. https://doi.org/10.34142/HSR.2020.06.04.02
\end{abstract}

\begin{abstract}
Aim: to determine how the motivations and backgrounds of students in Physical Education and recreation in the Physical Education and Recreation Study Program, Lampung University.

Material and methods. The method used in this research is a survey method with data collection techniques by distributing questionnaires to all students who are studying in the Lampung University Recreational Physical Education Study Program. The instrument used in this study was a questionnaire consisting of questions about student motivation to enter Lampung University Physical Education Study and additional questions about student backgrounds, school origins and data about students' parents. The shape of the instrument is in the form of multiple choice with a variety of choices, this gives the opportunity for students to choose according to the actual situation. The research sample was determined by census, namely all undergraduate students of Physical Education and Research, Lampung University consisting of 66 undergraduate students who were currently actively attending lectures.

Results. From the results of the study, it can be seen that the motivation to enter FKIP in the Penjaskesrek study program, Lampung University was more through the Academic PMDK compared to admissions through SPMB and PMDK Achievement and Talent. Of these, some students who enter the Physical Education study program are motivated because they want to become teachers, join ABRI or train. From this situation it is hoped that their interest will grow in fostering sports that are of interest and from them it is hoped that success in increasing sports achievements both at the regional and national levels. The number of students admitted to the Physical Education and Recreation study program amounted to 72 people, but only 66 students returned the questionnaire, which means more than $50 \%$ so that this research can be said to have represented the Physical Education and Recreation students.

Conclusions. Received, that of the 66 students of the Physical Education and Recreation study program, 27 people or $40 \%$ were accepted through SNMPTN, 23 people or $34.84 \%$ were accepted through the SBMPTN, 14 students or $21.21 \%$ were accepted through Mandiri and 2 people or $3.03 \%$ were accepted via PMPAT.
\end{abstract}

Keywords: Motivation, Student, Physical Education 


\title{
Анотація
}

Акор Сітепу, Ардіан Кахіаді, Герман Таріган. Мотивація студентів під час вступу на навчання за освітньою програмою «Фізичне виховання і рекреація»

Мета: визначення мотивації і рівня підготовки студентів в галузі фізичного виховання та рекреації в рамках навчальної програми «Фізичне виховання і рекреація» в Університеті в Лампунгі.

Матеріал і методи. Метод, використаний в цьому дослідженні, є метод опитування з методами збору даних шляхом роздачі анкет всім студентам, які навчаються фізичного виховання при університеті в Лампунгі. Інструмент, використаний в цьому дослідженні, був анкету, що складається з питань про мотивацію студентів до вступу на курс фізичного виховання в університеті в Лампунгі, а також додаткових питань про студентське минуле, шкільному походження і даних про батьків студентів. Форма інструменту має форму множинного вибору 3 безліччю варіантів вибору, що дає студентам можливість вибирати відповідно з реальною ситуацією. Вибірка для дослідження була визначена шляхом перепису. У ісследжованіі пріінялі участь всі студенти бакалаврату факультету фізичного виховання і досліджень Університету в Лампунгі (66 студентів), які в даний час активно відвідують лекції.

Результати. 3 результатів дослідження видно, що мотивація для вступу на освітню програму «Фізичне виховання і рекреація» в Університет в Лампунгі була більше через Академічну інформацію в порівнянні з надходженням через досягнення і таланти. 3 них багато студентів, які вступають на програму навчання з фізичного виховання, мотивовані, тому що хочуть стати вчителями, тренерами або тренуватися. У цій ситуації можна сподіватися, що їх інтерес до розвитку видів спорту, які представляють інтерес, буде рости, і від них можна сподіватися на успіх в підвищенні спортивних досягнень як на регіональному, так і на національному рівнях. Кількість студентів, допущених до програми вивчення фізичного виховання та рекреації, склало 72 людини, 66 студентів брали участь в анкетуванні, що становить більше 50\%. Таким чином, дослідження представляло студентів фізичного виховання та рекреації.

Висновки. Було виявлено, що з 66 студентів навчальної програми фізичного виховання і відпочинку 27 осіб або 40\% надійшли через отримання академічної інформації про цю програму, 23 людини або 34,84\% надійшли завдяки талантам і досягненням (з них більшість студентів хочуть стати вчителями, тренерами або підвищити свої спортивні досягнрення), 14 студентів або 21,21\% надійшли, отримавши інформацію від друзів і 2 людини або 3,03\% надійшли, отримавши інформацію від батьків.

Ключові слова: мотивація, студент, фізичне виховання

\begin{abstract}
Аннотация
Акор Ситепу, Ардиан Кахиади, Герман Тариган. Мотивация студентов при поступлении на обучение по образовательной программе «Физическое воспитание и рекреация»

Цель: определение мотивации и уровня подготовки студентов в области физического воспитания и рекреации в рамках учебной программы «Физическое воспитание и рекреация» в Университете в Лампунге.

Материал и методы. Метод, использованный в этом исследовании, представляет собой метод опроса с методами сбора данных путем раздачи анкет всем студентам, обучающимся физическому воспитанию при университете в Лампунге. Инструмент, использованный в этом исследовании, представлял собой анкету, состоящую из вопросов о мотивации студентов для поступления на курс физического воспитания в университете в Лампунге, а также дополнительных вопросов о студенческом прошлом, школьном происхождении и данных о родителях студентов. Форма инструмента имеет форму множественного выбора с множеством вариантов выбора, что дает студентам возможность выбирать в соответствии с реальной ситуацией. Выборка для исследования была определена путем переписи. В исследжовании прииняли участие все студенты бакалавриата факультета физического воспитания и исследований Университета в Лампунге (66 студентов), которые в настоящее время активно посещают лекции.

Результаты. Из результатов исследования видно, что мотивация для поступления на образовательную программу «Физическое воспитание и рекреация» в Университет в Лампунге была больше через Академическую информацию по сравнению с поступлением через достижения и таланты. Из них больщшинство студентов, которые поступают на программу обучения физическому воспитанию, мотивированы, потому что хотят стать учителями, тренерами или тренироваться. В этой ситуации можно надеяться, что их интерес к развитию видов спорта, которые представляют интерес, будет расти, и от них можно надеяться на успех в повышении спортивных достижений как на региональном, так и на национальном уровнях. Количество студентов, допущенных к программе изучения физического воспитания и рекреации, составило 72 человека, 66 студентов участвовали в анкетированнии, что составляет более 50\%. Таким образом, исследование представляло студентов физического воспитания и рекреации.

Выводы. Было выявлено, что из 66 студентов учебной программы физического воспитания и отдыха 27 человек или 40\% поступили через получение академической информации о данной программе, 23 человека или $34,84 \%$ поступили благодаря талантам и достижениям (из них большинство хочет стать учителями, тренерами ил повысить свои спортивные достижения), 14 студентов или 21,21\% поступили, получив информацию от друзей и 2 человека или 3,03\% поступили, получив информацию от родителей.
\end{abstract}

Ключевые слова: мотивация, студент, физическая культура 


\section{Introduction}

Many factors determine student learning outcomes [1]. The factors that determine student learning outcomes are divided into five blocks, namely: (a) individual student blocks which include changes, such as gender, age, attitudes towards school and academics, and the concept of me, (b) the school environment block includes changes in location school, group social pressure, the amount of time to do work, home, and so on, (c) block student backgrounds, including changes related to socioeconomic status, size of family members, number of siblings, birth order, and so on, (d) composite change of class and individual students, and (e) scores of intelligence tests.

Meanwhile, learning achievement related to motor skills is determined by three important factors, namely students (students), learning process factors, and situational factors [2]. Personal factors that differentiate one another that affect learning outcomes [3]. The factors are: acuity, perception, intelligence, body size that affects experience, emotions, motivation, behavior, other personality factors, gender and age. Motivation is a condition in a person's personality that encourages individual desire to carry out certain activities in order to achieve goals [4]. From the description above, it can be concluded that motivation plays an important role in human efforts to achieve a goal [5]. How big is the role of motivation in determining one's success [6]. Many terms are often used and have the same meaning as motivation [7], but from the many limitations and terms it can be shown that motivation contains a force or force that causes a person to be compelled to carry out certain activities in order to meet needs [8].

At first, motivation was explained with the concept of homeostasis, but because personal and social conditions play an important role in the behavior of sportsmen, current motivation is seen or explained by the theory of needs. Both intristic and extristic motivations have the power to achieve sporting achievement [9]. However, educators or coaches who are professional in instilling motivation from (self motivation) to their students are a moral responsibility that must be done to achieve the expected goals [10].

Motivation is often called people with motives only to show why someone does something [11]. Motivation and motive are two terms that are difficult to distinguish and it is not uncommon for people to use these different terms to be the same in the use of words or sentences both in terms of speech and writing to reach the answer between the words motive and motivation [12]. Motivation, attitudes, interests, which provide the possibility to encourage someone to act and behave [13]. To encourage someone to achieve the activity of the desired goal [14].

Motivation has a positive or negative effect on motor activity so that generalizations cannot be done for all situations [15]. But in general, an increase in motivation above the average is very beneficial for the achievement of sports achievement [16]. High motivation is beneficial for motor tasks including sports that involve elements of speed, strength and endurance (gross motor) in addition to being useful for simple motor tasks (simple motor tasks) [17].

High motivation will hinder achievement related to fine motor movements, coordination, steadiness (calm) and coordination [18], as well as hinder the learning process associated with complex motor tasks [3]. In general, the term motivation refers to the factors and processes that are meant to encourage people to act or not to act in various situations [19].

Judging from the background of students who enter the Penjaskesrek study program, each student has a different motivation. This can be seen from the results of this study. Motivations for someone to choose a career as a coach vary [20]. There are students who choose this career because by becoming a coach he will be able to apply his knowledge and skills to others; there are those who enjoy helping athletes and find satisfaction when the athletes show an increase in performance.

\section{Matherials and methods}

The method used in this research is the survey method with the ata technique by distributing questionnaires to all students who are currently studying at the Recreation Physical Education Study Program, Lampung University.

The instrument used in this study was a questionnaire consisting of questions about student motivation to enter the recreation physical education study program, Lampung University. and additional questions about student background, school origins and data about students' parents.

The shape of the instrument is a multiple choice form with a variety of choices, this gives the opportunity for students to choose according to the actual situation. Before the test is carried out, students are given an explanation related to how to answer the questions asked so that there are no errors in filling them, such as students do not need to 
include their identity so that the results obtained are more valid.

The research sample was determined by census, namely all undergraduate students who were studying at the Lampung University recreational physical education study program consisted of 66 undergraduate students who were actively attending lectures. The data analysis technique of this research is carried out by means of a description which is calculated by means of a percentage [21].

The calculation of the reliability coefficient in this study uses the mathematics software SPSS version 25 .

\section{Results}

\section{Validity Test}

For the calculation of the above instruments using mathematical software, namely SPSS version 25. Before testing the instrument, the statement items totaled 17 items. But after testing from the table above there are 2 invalid statement items because $r$ count (rxy) is less than $r$ table (0.456), namely items number 16 and 17 . The 15 valid statement items can be seen in the table 1 :

Instrument Validity Calculation Results

\begin{tabular}{ccccc}
\hline Number & $\begin{array}{c}\text { Scale Mean if Item } \\
\text { Deleted }\end{array}$ & $\begin{array}{c}\text { Scale Variance if } \\
\text { Item Deleted }\end{array}$ & $\begin{array}{c}\text { Corrected Item- Total } \\
\text { Correlation }\end{array}$ & Information \\
\hline Question_1 & 327.92 & 5174.341 & 0.612 & Valid \\
\hline Question_2 & 327.75 & 5179.239 & 0.551 & Valid \\
\hline Question_3 & 327.50 & 5181.739 & 0.584 & Valid \\
\hline Question_4 & 327.79 & 5150.172 & 0.781 & Valid \\
\hline Question_5 & 327.67 & 5173.188 & 0.703 & Valid \\
\hline Question_6 & 327.92 & 5174.341 & 0.612 & Valid \\
\hline Question_7 & 327.67 & 5173.188 & 0.703 & Valid \\
\hline Question_8 & 327.79 & 5150.172 & 0.781 & Valid \\
\hline Question_9 & 327.50 & 5181.739 & 0.584 & Valid \\
\hline Question_10 & 327.75 & 5171.848 & 0.755 & Valid \\
\hline Question_11 & 327.67 & 5173.188 & 0.703 & Valid \\
\hline Question_12 & 327.79 & 5150.172 & 0.781 & Valid \\
\hline Question_13 & 327.50 & 5181.739 & 0.584 & Valid \\
\hline Question_14 & 328.04 & 5162.389 & 0.548 & Valid \\
\hline Question_15 & 328.08 & 5185.384 & 0.526 & Valid \\
\hline Question_16 & 327.54 & 5169.998 & 0.267 & Invalid \\
\hline Question_17 & 327.42 & 5184.428 & 0.197 & \\
\hline
\end{tabular}

\section{Reliability Test}

The calculation of the reliability coefficient uses the Alpha Coefficient formula, as follows:

$\mathrm{rtt}=\frac{k}{k-1}\left(1-\frac{\text { varians korbutir tes }}{\text { varians kortes }}\right)$

Information:

$\mathrm{rtt}=$ Alpha Coefficient

$\mathrm{k}=$ Number of questions

varian $=$ Standard deviation squared

Table 2

Output Reliability SPSS version 25 Reliability Statistics

\begin{tabular}{cc} 
Cronbach's Alpha & N of Items \\
\hline 0.764 & 66
\end{tabular}

From the output image above, it is known that the Alpha value is 0.764 .

3. Description of the Research Results Questionnaire

Of the 15 questionnaires that have been distributed to 66 respondents, the questionnaire was from S-1 students of the FKIP Recreational Physical Education Study Program, Lampung University. After being checked, it turned out that from the 66 questionnaires that returned it turned out that all of the questionnaires met the filling requirements listed in the filling instructions. The formula for finding the percentage of the results of the questionnaire [22], according to: 
$p=f / n \times 100$

p: Percentage

f: Frequency of each questionnaire answer

$\mathrm{n}$ : Number of respondents

Table 3

Student admission

\begin{tabular}{cccc} 
Number & Path & $\begin{array}{c}\text { Total } \\
\text { Respondents }\end{array}$ & $\begin{array}{c}\text { Percentage } \\
(\%)\end{array}$ \\
\hline 1 & SNMPTN & 27 & 40.90 \\
\hline 2 & SBMPTN & 23 & 34.84 \\
\hline 3 & MANDIRI & 14 & 21.21 \\
\hline 4 & PMPAP & 2 & 3.03 \\
\hline Total & & 66 & 100
\end{tabular}

The number of questionnaires processed was 66 and after being counted manually, it turned out that 27 people or $40.90 \%$ of students entered through the SNMPTN route, 23 people or $34.84 \%$ of students entered through the SBMPTN Students who entered through the Independent College were 14 students or $21,21 \%$ and 2 people or $3.03 \%$ of students entered through PMPAP.

Table 4

Questions 1. Motivation to enter FKIP, Penjaskesrek Department, Lampung University

\begin{tabular}{|c|c|c|c|}
\hline Number & $\begin{array}{l}\text { Choice Of } \\
\text { Questions }\end{array}$ & Respondents & $\begin{array}{c}\text { Percentage } \\
(\%)\end{array}$ \\
\hline 1 & $\begin{array}{l}\text { Want to } \\
\text { be ABRI }\end{array}$ & 10 & 15.15 \\
\hline 2 & $\begin{array}{l}\text { Because I } \\
\text { like sports }\end{array}$ & 29 & 43.93 \\
\hline 3 & $\begin{array}{l}\text { Take the } \\
\text { lecture } \\
\text { lightly }\end{array}$ & 0 & 0 \\
\hline 4 & $\begin{array}{l}\text { Because I } \\
\text { joined my } \\
\text { friends }\end{array}$ & 0 & 0 \\
\hline 5 & $\begin{array}{l}\text { Parents' } \\
\text { will }\end{array}$ & 3 & 4.54 \\
\hline 6 & $\begin{array}{l}\text { Want to } \\
\text { be a } \\
\text { teacher or } \\
\text { coach }\end{array}$ & 23 & 34.84 \\
\hline 7 & $\begin{array}{c}\text { Originally } \\
\text { studying in } \\
\text { college }\end{array}$ & 0 & 0 \\
\hline 8 & $\begin{array}{l}\text { For other } \\
\text { reasons }\end{array}$ & 1 & 1.51 \\
\hline Total & & 66 & 100 \\
\hline
\end{tabular}

In the first question, it can be seen that of the 66 students, it turns out that only 29 students or $43.93 \%$ enjoy sports, while those who want to become sports teachers are 23 students or $34.84 \%$, who become ABRI 10 students or $15.15 \%$ (Table 5).

Table 5

Question 2. Parent's address

\begin{tabular}{cccc}
\hline Number & $\begin{array}{c}\text { Choice Of } \\
\text { Questions }\end{array}$ & Respondents & $\begin{array}{c}\text { Percentage } \\
(\%)\end{array}$ \\
\hline 1 & $\begin{array}{c}\text { Within the } \\
\text { city of } \\
\text { Bandar } \\
\text { Lampung }\end{array}$ & 24 & 36.36 \\
\hline \multirow{2}{*}{$\begin{array}{c}\text { From the } \\
\text { level II } \\
\text { Prov. } \\
\text { Lampung }\end{array}$} & 35 & 53.03 \\
\hline 3 & $\begin{array}{l}\text { Outside } \\
\text { the } \\
\text { Lampung } \\
\text { Region }\end{array}$ & 7 & 10.60 \\
\hline & & 100 \\
\hline
\end{tabular}

From the second question, it turns out that from 66 students 35 students or $53.03 \%$ came from the second level area of Lampung province and 24 students or $36.36 \%$ came from the city of Bandar Lampung, while 7 students or $10.60 \%$ came from outside Lampung (Table 6).

Table 6

Question 3. Parents (Father) Occupation

\begin{tabular}{cccc}
\hline Number & $\begin{array}{c}\text { Choice Of } \\
\text { Questions }\end{array}$ & Respondents & $\begin{array}{c}\text { Percentage } \\
(\%)\end{array}$ \\
\hline 1 & Farmer & 16 & 24.24 \\
\hline 2 & Traders & 9 & 13.63 \\
\hline 3 & Teacher & 5 & 7.57 \\
\hline 4 & $\begin{array}{c}\text { Government } \\
\text { employees }\end{array}$ & 14 & 21.21 \\
\hline 5 & ABRI & 3 & 4.54 \\
\hline 6 & Etc & 19 & 28.78 \\
\hline & Total & 66 & 100 \\
\hline
\end{tabular}

The question about the work of parents (father) turns out that most of the 66 students come from farmers' children, totaling 16 students or 24.24\% Civil Servants, amounting to 19 students $21.21 \%$, traders 9 students $13.63 \%$ (Table 7). 
Table 7

Question 4. Parents (Mother) Occupation

\begin{tabular}{cccc}
\hline Number & $\begin{array}{c}\text { Choice Of } \\
\text { Questions }\end{array}$ & Respondents & $\begin{array}{c}\text { Percentage } \\
(\%)\end{array}$ \\
\hline 1 & Farmer & 7 & 10.60 \\
\hline 2 & Traders & 7 & 10.60 \\
\hline 3 & Teacher & 4 & 6.06 \\
\hline 4 & $\begin{array}{c}\text { Government } \\
\text { employees }\end{array}$ & 15 & 22.72 \\
\hline 5 & Etc & 33 & 50 \\
\hline & Total & 66 & 100 \\
\hline
\end{tabular}

Mother's occupation turned out to be 15 people or $22.72 \%$ as Civil Servants, 4 teachers or $6.06 \%$, while farmers and traders consisted of 7 people or $10.60 \%$ respectively (Table 8 ).

Question 5. Father

\begin{tabular}{cccc}
\hline Number & $\begin{array}{c}\text { Choice Of } \\
\text { Questions }\end{array}$ & Respondents & $\begin{array}{c}\text { Percentage } \\
\text { (\%) }\end{array}$ \\
\hline 1 & $\begin{array}{c}\text { Daddy } \\
\text { Exercises } \\
\text { Often }\end{array}$ & 35 & 53.03 \\
\hline 2 & $\begin{array}{c}\text { Dad } \\
\text { doesn't } \\
\text { exercise } \\
\text { often }\end{array}$ & 31 & 46.96 \\
\hline & Total & 66 & 100 \\
\hline
\end{tabular}

The question of whether the father likes to exercise turns out to be 35 parents of students or $53.03 \%$ who often exercise while 31 parents who do not exercise often or $46.96 \%$ (Table 9).

Table 9

Question 6. Mother

\begin{tabular}{cccc}
\hline Number & $\begin{array}{c}\text { Choice Of } \\
\text { Questions }\end{array}$ & Respondents & $\begin{array}{c}\text { Percentage } \\
(\%)\end{array}$ \\
\hline 1 & $\begin{array}{c}\text { Mother } \\
\text { Exercise } \\
\text { Often }\end{array}$ & 24 & 36.36 \\
\hline 2 & $\begin{array}{l}\text { Mother } \\
\text { doesn't } \\
\text { exercise } \\
\text { often }\end{array}$ & 42 & 63.63 \\
\hline & 66 & 100 \\
\hline
\end{tabular}

In contrast to fathers, mothers who often exercise consisted of 24 student mothers or $36.36 \%$ and mothers who did not often exercise were 42 students or $63.63 \%$. The question of whether the father likes to watch sports, the result is 44 fathers who often watch sports events or $66.66 \%$ while the fathers who don't often watch sports are 22 fathers or $33.33 \%$. The same question was submitted to the mothers of students, it turned out that only 11 mothers or $16.66 \%$ often watched sports events, while 55 mothers $83.33 \%$ apparently did not watch sports often.

When asked about whether there are siblings who have sports achievements, it turns out that 29 people $43.93 \%$ answered yes and 37 people or $56.06 \%$ did not have siblings who had sports achievements. In the question whether there are families who have national achievements in sports, 14 students or $21.21 \%$ have families who have national achievements and 52 people or $78.78 \%$ of students have families who have national achievements in the field of sports.

In general, the students of the Physical Education and Recreation Study Program in 2015 consisted of 50 students $75.75 \%$ from Senior High School (SMA), 7 students $10.60 \%$ from Engineering Vocational Schools, 2 students 3.03\% from SMK (SMEA) and from other schools amounted to 7 people or $10.60 \%$ (Table 10).

Table 10

Question 12. As a sportsman

\begin{tabular}{cccc}
\hline Number & $\begin{array}{c}\text { Choice Of } \\
\text { Questions }\end{array}$ & Respondents & $\begin{array}{c}\text { Percentage } \\
(\%)\end{array}$ \\
\hline 1 & $\begin{array}{c}\text { In high } \\
\text { school as a } \\
\text { sportsman }\end{array}$ & 47 & 71.21 \\
\hline $\begin{array}{c}\text { At high } \\
\text { school not } \\
\text { as a } \\
\text { sportsman }\end{array}$ & 19 & 28.78 \\
\hline & 66 & 100 \\
\hline
\end{tabular}

Question 12 which asked whether students at high school were sportsmen, the answers of the students were 47 students, $71.21 \%$ as sportsmen and 19 students, $28.78 \%$, who answered not as sportsmen (Table 11).

Table 11

Question 13. Sports status at high school

\begin{tabular}{cccc}
\hline Number & $\begin{array}{c}\text { Choice Of } \\
\text { Questions }\end{array}$ & Respondents & $\begin{array}{c}\text { Percentage } \\
(\%)\end{array}$ \\
\hline 1 & $\begin{array}{c}\text { Not a } \\
\text { sportsman }\end{array}$ & 6 & 9.09 \\
\hline 2 & $\begin{array}{c}\text { Ordinary } \\
\text { sportsman }\end{array}$ & 15 & 22.72 \\
\hline 3 & $\begin{array}{c}\text { Village } \\
\text { team }\end{array}$ & 3 & 4.54 \\
\hline 4 & $\begin{array}{c}\text { School } \\
\text { team }\end{array}$ & 23 & 34.84 \\
\hline 5 & $\begin{array}{c}\text { City / area } \\
\text { team }\end{array}$ & 13 & 19.69 \\
\hline 6 & $\begin{array}{c}\text { National } \\
\text { team }\end{array}$ & 6 & 9.09 \\
\hline & Total & 66 & 100 \\
\hline
\end{tabular}


The status of Physical Education students when in high school was 6 people $9.09 \%$ not as sportsmen, 15 students $22.72 \%$ as sportsmen, 3 people $4.54 \%$ joined the village team, 23 people 34 , $84 \%$ as school teams, 13 people $19.69 \%$ were selected as the city / regional team and 6 people $9.09 \%$ were selected as the National team (Table 12).

Table 12

Question 14. The amount of practicing sports in high school

\begin{tabular}{cccc}
\hline Number & $\begin{array}{c}\text { Choice Of } \\
\text { Questions }\end{array}$ & Respondents & $\begin{array}{c}\text { Percentage } \\
\text { (\%) }\end{array}$ \\
\hline 1 & $\begin{array}{c}\text { Not } \\
\text { practicing }\end{array}$ & 9 & 13.63 \\
\hline 2 & $\begin{array}{c}\text { One time } \\
\text { practice }\end{array}$ & 4 & 6.06 \\
\hline 3 & $\begin{array}{l}\text { Twice to } \\
\text { practice }\end{array}$ & 4 & 6.06 \\
\hline 4 & $\begin{array}{l}\text { Three } \\
\text { times } \\
\text { practice }\end{array}$ & 15 & 22.72 \\
\hline 5 & $\begin{array}{l}\text { More than } \\
\text { three } \\
\text { times } \\
\text { practicing }\end{array}$ & 34 & 51.51 \\
\hline & Total & 100 \\
\hline
\end{tabular}

Of the 66 Physical Education students, it turns out that 9 people $13.63 \%$ have never practiced sports while in high school and 34 students often practice sports or $51.51 \%$ (Table 13).

Table 13

Question 15. Have a favorite athlete

\begin{tabular}{cccc}
\hline Number & $\begin{array}{c}\text { Choice Of } \\
\text { Questions }\end{array}$ & Respondents & $\begin{array}{c}\text { Percentage } \\
\text { (\%) }\end{array}$ \\
\hline \multirow{2}{*}{$\begin{array}{c}\text { At SMTA } \\
\text { have } \\
\text { favorite } \\
\text { athletes }\end{array}$} & 35 & 53.03 \\
\hline \multirow{2}{*}{$\begin{array}{c}\text { In high } \\
\text { school, } \\
\text { you don't } \\
\text { have } \\
\text { favorite } \\
\text { athletes }\end{array}$} & 31 & 46.96 \\
\hline & & \\
\hline Total & 66 & 100 \\
\hline
\end{tabular}

Regarding the students' hobbies towards sports, it turns out that 35 students, $53.03 \%$, have favorite athletes and 31 students $46.96 \%$ of students do not have favorite athletes.

\section{Discussion}

The research that is almost similar is research from Sandi Akbar Romadhon, Tri Rustiadi [20]: the purpose of this study was to to determine the motivation and interest of the community exercise bike in the city of Semarang. The population in this study werepeople who exercise bike in the city of Semarang. The sample in this study were 62 people who went through the exercise bike, especially in the car freeday Semarang Simpangfive sampling incidental manner. Sampling technique used is total sampling. Data collection by survey method with questionnaire. Data from the instrument questionnaire prepared by the method of analytical description of the percentage. From the analysis shows that the majority of people in exercise bikes as motivation number 34 people in the category of good, 28 in the category very well, and no one in the category of less good or less, and their interest in a number of 23 people in the category very good , 37 people fall into either category, two people fall into the category of less good, and there is no entry in the category is less. The conclusion that the dominant of the community sample who exercise bike in the city of Semarang dominant fall into either category. These results indicate that both in terms of interest or motivationis in good category.

From the results of the study, it can be seen that the motivation to enter the FKIP Recreational Physical Education Study Program at the Lampung University is more likely to enter through the Academic PMDK compared to admissions through SPMB and PMDK Achievement and Talent. Of these, some students who enter the Physical Education study program are motivated because they want to become teachers, join ABRI or train. From this situation it is hoped that their interest will grow in fostering sports that are of interest and from them it is hoped that success in increasing sports achievements both at the regional and national levels. Whereas those who have motivation because they enjoy sports are less than the desire to be a teacher, this will benefit the local government in achieving optimal sports performance through physical education in schools, from this result it means that the situation in the Recreation Physical Education Study Program at the Lampung University is in accordance with his soul where the Physical Education Department is under the auspices of the science education department.

From the school background, parents and sports are expected to help determine the results of student studies while studying at the Recreation Physical Education Study Program at the Lampung 
University. The things that benefit student studies are: Most of the student residences come from the Lampung province; Students enrolled in the Recreational Physical Education Study Program at the Lampung University on average because they want to become teachers, ABRI or trainers, this can be seen from the backgrounds of their parents, siblings and family who are less interested in sports. Parents of students work mostly as civil servants, this allows their children to follow in the footsteps of their parents as civil servants. As long as the average student's school comes from high school, on the basis of the educational background students are expected to complete their education more quickly at the Lampung University recreational physical education study program. Good student sports background experienced at high school.

\section{Conclusion}

The number of students admitted to the Physical Education and Recreation study program amounted to 72 people, but only 66 students returned the questionnaire, which means more than $50 \%$ so that this research can be said to have represented the Physical Education and Recreation students.

Of the 66 students of the Physical Education and Recreation study program, 27 people or $40 \%$ were accepted through SNMPTN, 23 people or $34.84 \%$ were accepted through the SBMPTN, 14 students or $21.21 \%$ were accepted through Mandiri and 2 people or $3.03 \%$ were accepted via PMPAT.

\section{Conflict of interest}

The authors declare that there is no conflict of interest.

\section{References}

1. Anderson PH, Hubbard A, Lawton L. Student Motivation to Study Abroad and Their Intercultural Development. Front Interdiscip J Study Abroad. 2015;

2. Shaleh M. Pengaruh motivasi, faktor keluarga, lingkungan kampus dan aktif berorganisasi terhadap prestasi akademik. Phenom J Pendidik MIPA. 2016.

3. De Meyer J, Soenens B, Vansteenkiste M, Aelterman N, Van Petegem S, Haerens L. Do students with different motives for physical education respond differently to autonomy-supportive and controlling teaching? Psychology of Sport and Exercise. 2016.

4. König J, Rothland M. Motivations that affect professional knowledge in Germany and Austria. In: Global Perspectives on Teacher Motivation. 2017.

5. Muttaqin A, Ifwandi, Jafar M. Motivasi Member Fitness Center Dalam Melakukan Latihan Kebugaran Jasmani (Studi Kasus Pada Member Wana Gym Banda Aceh Tahun 2015). J Ilm Mhs Pendidik Jasmani, Kesehat dan Rekreasi. 2016.

6. Aritonang KT. Minat dan Motivasi dalam Meningkatkan Hasil Belajar Siswa. J Pendidik Penabur. 2008.

7. Minat, motivasi dan kemahiran mengajar guru pelatih. J Pendidik Malaysia. 2006;

8. Rosenkranz SK, Wang S, Hu W. Motivating medical students to do research: A mixed methods study using Self-Determination Theory Career choice, professional education and development. BMC Med Educ. 2015.

9. Nurhidayah. Faktor-Faktor Yang Mempengaruhi Motivasi Belajar. J Prodi PGSD UAD. 2014.
10. Rosenkranz SK, Wang S, Hu W. Motivating medical students to do research: A mixed methods study using Self-Determination Theory. BMC Med Educ. 2015.

11. Heim R. Motivation. In: Structural Integrity. 2020.

12. Reiss S. Intrinsic and Extrinsic Motivation. Teaching of Psychology. 2012.

13. Lai ER. Motivation: A Literature Review Research. Res Reports. 2011.

14. Light RL, Harvey S. Positive Pedagogy for sport coaching. Sport Educ Soc. 2017.

15. Ryan F. Motivation and Engagement. In: Cognitive Therapy for Addiction. 2013.

16. Aji GL. Self-Regulated Learning pada Mahasiswa Tahun Pertama. Skripsi. 2016.

17. Richardson KP. Physical Education Teacher Education. J Phys Educ Recreat Danc. 2011.

18. Andjarwati T. Motivasi dari Sudut Pandang Teori Hirarki Kebutuhan Maslow, Teori Dua Faktor Herzberg, Teori xy Mc Gregor, dan Teori Motivasi Prestasi Mc Clelland. J Ilmu Ekon Dan Manaj. 2015.

19. Johnson JE, Giannoulakis C, Felver N, Judge LW, David PA, Scott BF. Motivation, Satisfaction, and Retention of Sport Management Student Volunteers. J Appl Sport Manag. 2017.

20. Sandi Akbar Romadhon TR. Motivasi dan minat masyarakat dalam berolahraga sepeda di kota semarang. Act - J Phys Educ Sport Heal Recreat. 2016;5(1):24-8.

21. Hilgers R-D, Heussen N, Stanzel S. Statistik, deskriptive. In: Lexikon der Medizinischen Laboratoriumsdiagnostik. 2018.

22. Sugiyono, Republik Indonesia. Metode Penelitian Kuantitatif \& kualitatif. Journal of Experimental Psychology: General 2010. 


\section{Information about the authors}

\section{Akor Sitepu}

akor.sitepu@fkip.unila.ac.id

https://orcid.org/0000-0002-6538-0310

Lampung University

Street. Prof. Dr. Sumantri Brojonegoro No.1, Bandar Lampung City, Lampung, Indonesia

\section{Ardian Cahyadi}

ardian.cahyadi@fkip.unila.ac.id

https://orcid.org/0000-0001-7919-3295

Lampung University

Street. Prof. Dr. Sumantri Brojonegoro No.1, Bandar Lampung City, Lampung, Indonesia

\section{Herman Tarigan}

herman@fkip.unila.ac.id

https://orcid.org/0000-0002-1143-8652

Lampung University

Street. Prof. Dr. Sumantri Brojonegoro No.1, Bandar Lampung City, Lampung, Indonesia

\section{Інформація про авторів}

\section{Акор Сітепу}

akor.sitepu@fkip.unila.ac.id

https://orcid.org/0000-0002-6538-0310

Університет в Лампунгі

Вул. профессора доктора Самантрі Бройонегоро, 1, м. Бандар Лампунг, Лампунг, Індонезія

\section{Ардіан Кахіаді}

ardian.cahyadi@fkip.unila.ac.id

https://orcid.org/0000-0001-7919-3295

Університет в Лампунгі

Вул. профессора доктора Самантрі Бройонегоро, 1, м. Бандар Лампунг, Лампунг, Індонезія

\section{Герман Таріган}

herman@fkip.unila.ac.id

https://orcid.org/0000-0002-1143-8652

Університет в Лампунгі

Вул. профессора доктора Самантрі Бройонегоро, 1, м. Бандар Лампунг, Лампунг, Індонезія

\section{Информация об авторах}

\section{Акор Ситепу}

akor.sitepu@fkip.unila.ac.id

https://orcid.org/0000-0002-6538-0310

Университет в Лампунге

Ул. профессора доктора Самантри Бройонегоро, 1, г.. Бандар Лампунг, Лампунг, Индонезия

\section{Ардиан Кахиади}

ardian.cahyadi@fkip.unila.ac.id

https://orcid.org/0000-0001-7919-3295

Университет в Лампунге

Ул. профессора доктора Самантри Бройонегоро, 1, г.. Бандар Лампунг, Лампунг, Индонезия

\section{Герман Тариган}

herman@fkip.unila.ac.id

https://orcid.org/0000-0002-1143-8652

Университет в Лампунге

Ул. профессора доктора Самантри Бройонегоро, 1, г.. Бандар Лампунг, Лампунг, Индонезия

This work is licensed under a Creative Commons Attribution 4.0 International License (CC BY 4.0) 